ESJ Humanities

\title{
Promoting the Participation of Indigenous Peoples in Environmental Impact Assessment: Effectiveness of Akwé: Kon Guidelines in Finland
}

\author{
Vincent Onyango, PhD \\ Henri Wiman, MSc \\ Architecture \& Urban Planning, \\ University of Dundee, Scotland, United Kingdom
}

$\underline{\text { Doi:10.19044/esj.2021.v17n20p30 }}$

Submitted: 02 March 2021

Accepted: 24 June 2021

Published: 30 June 2021
Copyright 2021 Author(s)

Under Creative Commons BY-NC-ND

4.0 OPEN ACCESS

Cite As:

Onyango V. \& Wiman H. (2021). Promoting the Participation of Indigenous Peoples in Environmental Impact Assessment: Effectiveness of Akwé: Kon Guidelines in Finland. European Scientific Journal, ESJ, 17(20), 30. https://doi.org/10.19044/esj.2021.v17n20p30

\begin{abstract}
Indigenous peoples' participation in public policy and planning is ascribed in numerous international and national legal instruments as essential to the realisation of their self-determination. This study examines how the Akwé: Kon guidelines (AK) can promote effective indigenous peoples participation in environmental management, especially during environmental impact assessment (EIA). Special focus is drawn on the Finnish context, home of the Sámi indigenous people. The study applies an effectiveness review package by Lee and Colley (1999), supplemented by interview and questionnaire surveys, to analyse how effective the AK have been. It was found that although they were useful in promoting further interaction of the Sámi with authorities, the AK did not address their most fundamental political and legal grievances. This leaves room for EIA policy and practice, in Finland and all other jurisdictions with indigenous peoples, to consider how they can more effectively harness the potentialities in AK.
\end{abstract}

Keywords: Akwé: Kon Guidelines; Environmental Impact Assessment; Indigenous People; Participation; Sámi; Environmental management 


\section{Introduction}

Indigenous Peoples (IPs), also known as first peoples, aboriginal peoples, native peoples, or autochthonous peoples, are ethnic groups who are the original inhabitants of a given region, in contrast to groups that have subsequently settled, occupied or colonised the area (Guenther et al., 2006). Several treaties and national legislations bestow fundamental rights to IPs across various environmental governance and management matters (Macklem, 2008); with participation of IPs emerging as a key principle in formal decisionmaking processes e.g. Environmental Impact Assessment (EIA) and land-use planning (O'Faircheallaigh, 2007; Nygaard, 2016). This has elevated participation to a foremost tool for IPs to realise their self-determination and to protect their rights (Charters, 2010).

However, globally, IPs participation in environmental management is ridden with shortcomings (Bersaglio et al., 2014; Chebotarev \& Gladun, 2015; Fontana \& Grugel, 2016). This ranges from the generalisable process of public participation to the more unique experiences of IPs related to the dispossession of land, subjugation to state sovereignty, and denial of recognition, as IPs might not be considered legitimate users or owners of lands and waters (Beavies et al., 2015; Carter \& Ruwhiu, 2016). For some (Bersaglio et al., 2014; Booth \& Skelton, 2011; Simpson, 2006), the IP-state relationship is a specific case in which IPs interests are misrepresented and/or only given superficial attention.

This paper explores the extent to which Akwé: Kon Guidelines (AK), set up with the specific purpose of facilitating IPs participation in EIA, promoted IP participation in environmental management decisions. The study applies an effectiveness evaluation framework that adopts Sadler's (1996:37) definition of 'effectiveness' for the EIA context: "how well something works or whether it works as intended and meets the purposes for which it is designed". The significance of this work lies in benchmarking practice and highlighting areas for future intervention to enhance IPs effective participation in environmental management processes. With about 220 to 350 million IPs and over 100 uncontacted tribes around the world, insight from the study can help design EIA processes that better protect IPs's interests. The paper is based on data from Finnish case studies where AK was applied in relation to Finland's Sámi indigenous community.

\section{Background context}

\subsection{Practice and relevant studies}

Baker \& McLelland's (2003) evaluated the effectiveness of British Columbia's EIA process for First Nations' (IPs) participation in three mining case studies. Based on criteria across the procedural e.g. notification, access to information; substantive participation beyond voting and representation, 
and; and transactive e.g. time management, cost management dimensions of EIA. They concluded that effectiveness was low. Noble et al. (2016) and Booth \& Skelton (2011) explored practice-based challenges to IP participation in EIA in Canada, and identified late entry of IP participants as a common shortcoming; industry confusion on division of responsibilities in initiating IPs participation; lack of industry understanding of the need to integrate traditional knowledge in EIA; disagreement on exact legal obligations for impact assessments, and; a lack of alternative avenues for addressing IPs concerns.

Other scholars (Corbett \& O'Faircheallaigh, 2005; Carter \& Ruwhiu, 2016; Bersaglio et al., 2014) have found that Western development priorities are often paramount even when IPs participate, echoing findings from Australia (Banerjee, 2001) and Norway (Johnsen, 2016). Others have argued that recognition of multiple values and interests regarding the environment and benefit-sharing is a productive starting point for consultations with IPs (Barber \& Jackson, 2015; Collen et al., 2013). The legal standing of IPs in environmental management issues has also been identified (Simpson, 2006), alongside other factors for effective participation e.g. Trust (Flemmer \& Schilling-Vacaflor, 2016), power relations (Corbett \& O'Fairchaellaigh, 2005) and logistics (Minter et al., 2014). Overall, the literature identifies various challenges to IP participation, without outlining any ideal single solution. Rather, it suggests that it is more practical to acknowledge the challenges and shortcomings of various approaches whilst trying to engage as effectively as possible.

\subsection{Rights: The Akwé: Kon Guidelines}

A main achievement of the 7th conference of the parties of the Convention on Biological Diversity (CBD) in 2004 (UNEP, 2011), was the adoption (decision VII/16 F) of the Akwé: Kon Guidelines (AK) (CBD, 2004). 'Akwé: Kon' is a Mohawk phrase meaning 'everything in creation' or 'all of us'. These are voluntary guidelines for the conduct of cultural, health, economic, environmental and social impact assessments of proposed developments, which may impact on sacred sites, lands and waters traditionally occupied or used by IPs. The purpose of the guidelines is to help EIAs better consider impacts on IPs, so that decision-makers of developments can:

- Support full and effective participation of IPs in screening, scoping and development planning exercises;

- Properly consider the cultural, environmental and social concerns and interests of IPs, especially of women;

- Give due regard and consider the ownership of and the need for protecting and safeguarding the traditional knowledge, innovations and practices of IPs; 
- Promote the use of appropriate technologies and identify and implement appropriate measures to prevent or mitigate any negative impacts of proposed developments;

- Take into consideration the interrelationships among the cultural, environmental and social elements of IPs.

- AK emphasises IPs' rights to traditional knowledge and use of biological resources for traditional purposes - expressed in articles $8(\mathrm{j})$ and 10 (c) of the CBD. These rights are to be achieved via effective application of public participation procedures within EIA, following a ten-step process:

- Notification and public consultation of proposed development;

- Identification of IPs and relevant stakeholders;

- Establishment of effective mechanisms for IP participation, including women, youths, the elderly and other vulnerable groups;

- Establishment of an agreed process for recording stated views and concerns;

- Establishment of a process whereby IPs may accept or oppose a proposed development;

- Identification and provision of sufficient resources for effective IP participation in all procedures;

- Establishment of an environmental management or monitoring plan (EMP);

- Identification of the actors responsible for liability, redress, insurance and compensation;

- Mutual agreements between project proponents and IPs for implementing preventive or mitigatory measures;

- Establishment of a review and appeals process.

\subsection{Theory: participation and rights discourses}

Discourses in participation theories, practices and benefits, have been competently addressed for example in Driessen et al. (2013). O'Fairchaellaigh (2010), Howitt (2001), Charters (2010) and Hausam (2013) discuss power relations in participation; whilst Arnstein's (1969) 'ladder of public participation' hierarchically categorises different forms of citizen participation and how power is distributed to the participants (Figure 1). Blahna \& Keough (2005) argue that participants can shape the outcomes of decision-making without wielding any formal power by sharing the decision-making space. Kosko (2013:297) further warns that no person or group has total control over the future or over processes of change that affect them, and neither should someone else. 


\begin{tabular}{ll}
\hline Citation & Nature of 'power' or 'influence' \\
\hline Arnstein (1969) & $\begin{array}{l}\text { Power formally distributed to the public depending on type of } \\
\text { participation process. }\end{array}$ \\
\hline Goulet (1989) & $\begin{array}{l}\text { Power formally distributed to the public depending on point-of- } \\
\text { entry. }\end{array}$ \\
\hline $\begin{array}{l}\text { Blahna \& Keough } \\
\mathbf{( 2 0 0 5 )}\end{array}$ & $\begin{array}{l}\text { Influence on decision-making exerted informally through } \\
\text { openness. }\end{array}$ \\
\hline $\begin{array}{l}\text { Collen et al. } \\
(\mathbf{2 0 1 3 )}\end{array}$ & $\begin{array}{l}\text { Project success contingent on public participation and informal } \\
\text { power of the public. }\end{array}$ \\
\hline
\end{tabular}

Figure 1. Nature of power and influence - four broad perspectives of participation and power in decision-making

However, Driessen et al. (2013) and O'Fairchaellaigh (2010) criticise the notion of a 'public interest' within public participation, since the public is in fact made up of different interest groups and dialogue does not imply that every interest is considered. Howitt (2001) approaches environmental resource management as a necessarily political project, whilst Johnsen (2016) critiques the weaknesses of environmental management practice which aims either to build an evidence base for decisions or to overcome stakeholder differences through dialogue. Either aim can easily result in the prioritisation of specific types of arguments at the expense of others. This implies that an assessment of AK effectiveness, or any other indigenous participation policy, needs to be done without reference to notions of 'common interest' or 'ideal outcomes' although its normative rationale of IP empowerment cannot be overlooked.

The IPs legal and rights framework, beyond public participation, is now well established, based on existing binding and voluntary regulations. Today, IPs have the right to internal self-determination under International Covenant on Civil and Political Rights (1966). The United Nations Declaration on the Rights of Indigenous Peoples (UNGA, 2007; Niemivuo, 2015), is a source of common law as national courts and international human rights bodies invoke it (Collen et al., 2013). It goes beyond stakeholders' rights to participation, to emphasise the concept of rights-holders (Gneiting et al., 2009; Pogge, 2005; Harris-Curtis, 2003), which is a fundamental theory in IP matters. Rights-holders are individuals or social groups that have particular entitlements and can make legitimate claims in relation to specific dutybearers that are responsible and can be held accountable for their acts or omissions.

The Convention on Biological Diversity (1992) also gives indigenous and local communities the right to use natural resources for traditional purposes and grants them ownership of their traditional knowledge (Parks et al., 2019). The International Labour Organization's Convention (no. 169) ${ }^{1}$

${ }^{1}$ Finland is yet to complete its process of ratifying ILO C169. 
article 6(1) states that IPs should be consulted through their own representative institutions; article 7(1) gives IPs the right to decide their own priorities for the process of development, and; article 15(1) sets their rights to participate in the use, management, and conservation of the natural resources in their lands (Joona \& Joona, 2011).

In May 2016, the Fifteenth Session of the United Nations Permanent Forum on Indigenous Issues (UNPFII) affirmed that IPs (also termed aboriginal people, native people, or autochthonous people) are distinctive groups protected in international or national legislation as having a set of specific rights based on their linguistic and historical ties to a particular territory, prior to later settlement, development, and or occupation of a region. The session affirmed that since IPs are vulnerable to exploitation, marginalization, oppression, forced assimilation, and genocide by nation states formed from colonizing populations or by politically dominant, different ethnic groups, special protection of individuals and communities maintaining ways of life indigenous to their regions, are entitled to special protection. Thus, the rights to negotiation, quite distinct from the rights to participation and consultation procedures, are provided (Figure 2).

\begin{tabular}{|c|c|c|}
\hline $\begin{array}{l}\text { Participation } \\
\text { right }\end{array}$ & Regulation & Description \\
\hline \multirow[t]{2}{*}{$\begin{array}{l}\text { Consultation } \\
\text { right } \\
\text { (in force) }\end{array}$} & $\begin{array}{l}\text { Act on the Sámi } \\
\text { Parliament } \\
(974 / 1995) \text { section } \\
9(1)\end{array}$ & $\begin{array}{l}\text { Finnish authorities must negotiate with or hear the Sámi } \\
\text { Parliament on measures which directly affect Sámi status as } \\
\text { an IP. Direct interaction between Sámi Parliament and } \\
\text { authorities not required. }\end{array}$ \\
\hline & $\begin{array}{l}\text { Skolt Act } \\
(253 / 1995) \text { section } \\
56\end{array}$ & $\begin{array}{l}\text { Skolt Village Assembly can give a statement to authorities } \\
\text { on far-reaching measures which concern Skolt livelihoods } \\
\text { or living conditions. }\end{array}$ \\
\hline $\begin{array}{l}\text { Negotiation } \\
\text { right (bill at } \\
\text { time of study, } \\
\text { not in force) }\end{array}$ & $\begin{array}{l}\text { Government bill } \\
\text { HE } 167 / 2014\end{array}$ & $\begin{array}{l}\text { The negotiations intended by the Act on the Sámi } \\
\text { Parliament are a mode of participation which goes beyond a } \\
\text { hearing and includes direct interaction between the Sámi } \\
\text { Parliament and a government agency. }\end{array}$ \\
\hline CBD right & Regulation & Description \\
\hline $\begin{array}{l}\text { Rights to } \\
\text { traditional } \\
\text { knowledge }\end{array}$ & $\begin{array}{l}\text { Convention on } \\
\text { Biological } \\
\text { Diversity article } \\
8(j)\end{array}$ & $\begin{array}{l}\text { The Finnish state must respect, preserve, and maintain Sámi } \\
\text { traditional knowledge. The Sámi are entitled to fair and } \\
\text { equitable sharing of benefits arising from the utilisation of } \\
\text { their traditional knowledge. Sámi traditional knowledge can } \\
\text { be utilised by the consent of the Sámi. }\end{array}$ \\
\hline $\begin{array}{l}\text { Rights to use } \\
\text { biological } \\
\text { resources }\end{array}$ & $\begin{array}{l}\text { Convention on } \\
\text { Biological } \\
\text { Diversity article } \\
10(c)\end{array}$ & $\begin{array}{l}\text { The Sámi may use biological resources for traditional } \\
\text { purposes. }\end{array}$ \\
\hline
\end{tabular}

Figure 2: Rights criteria of effectiveness 


\section{Materials and methods}

3.1. The case study

Sámi participation rights are well established in Finland, which ratified the CBD with the term 'indigenous and local communities' referring only to the Sámi (Heinämäki, 2017). Finland's constitution (GoF, 1999a) also recognises the Sámi as an IP. Sámi participation and environmental rights are further regulated in the Act on the Sámi Parliament (GoF, 1995a), and the Skolt Act (253/1995), which aim to enhance the living conditions, culture and livelihoods of the Sámi (GoF, 1995b). Though Finland has a relatively high international reputation in upholding human rights it also gets regularly notified over its Sámi policies and legislation (Joona \& Joona, 2011; Allard et al., 2017; Anaya, 2011).

A decision to implement $\mathrm{AK}$ is included in the government action plan for environmental protection 2013-2020 (Ministry of the Environment, 2013). The Finnish translation of the AK apply to EIAs, Management and Use Plans, Natural Resource Plans, and County Plans (Figure 3) (Ministry of the Environment, 2011). The Finnish EIA framework requires that a liaison authority, called the Centre for Economic Development, Transport and the Environment (ELY-Centre), ensures that the project proponent recognises relevant comments made by the public (Jalava et al., 2014). 90\% of the Sámi homeland is state-owned and administered by Metsähallitus (Hyvärinen, 2010), a state-owned enterprise tasked with sustainably using, managing, and conserving state lands and waters (GoF, 2016).

\begin{tabular}{ll}
\hline Competent authority & Plan/assessment \\
\hline Metsähallitus & Management and Use Plans, Natural Resource Plans \\
\hline Lapin liitto & County plans \\
\hline ELY-Centre & Environmental Impact Assessment \\
\hline
\end{tabular}

Figure 3: Competent authorities and relevant environmental management tools. County plans in the Sámi homeland are drawn by the municipal union Lapin liitto.

A pilot AK project was completed in 2012 and a small number of other projects have started to follow AK (see Metsähallitus, 2013), making Finland's EIA application of AK a worthy source of lessons for the wider EIA community, especially where IPs are found.

\subsection{Methods and data collection}

\subsubsection{Effectiveness review}

Lee and Colley Review Package (Lee \& Colley, 1991; Lee et al., 1999), which has become a widely acknowldeed empirical method (see Simpson, 2001; Põder \& Lukki, 2011), was applied to key documents to evaluate the extent to which there was evidence that AK was effectively applied. The Review package is flexible and eaisly adaptable, and was 
appropraite in this study as it allowed for assessment at various levels and details, to see how quality differs across various factors. Starting from the lowest level of 15 categories and moving systematically up the review hierarchy, the quality of each review area was assessed (Figure 4) and the results then used to reach an overall assessment.

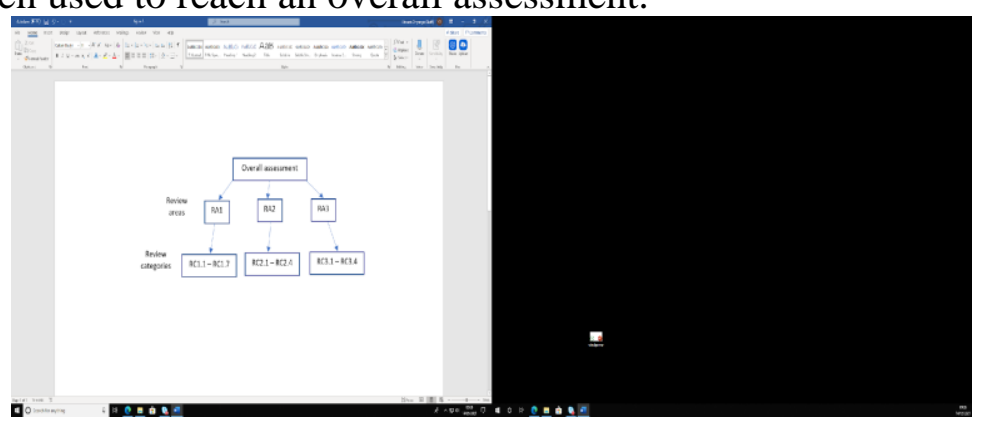

Figure 4. A schematic representation of the review hierarchy areas based on Lee et al.

(1999)

The evaluation framework facilitated the detailed assessment of the tasks (Table 1) identified from the literature (see sec 2). These were matched to the four commonly acknowledged dimensions of EIA effectiveness, i.e. procedural, substantive, transactive, and normative (Bond \& Chanchitpricha, 2013), to facilitate understanding of the various areas of effectiveness.

Table 1: 15 Review Categories (RCs) matched to the dimensions of EIA effectiveness, i.e. procedural [p], substantive [s], transactive [t] , and normative [n] (Totals: $\mathrm{p}=2 ; \mathrm{s}=7 ; \mathrm{n}=4$; $\mathrm{t}=2$ ).

\begin{tabular}{|c|c|}
\hline RA1. Information provision & Description \\
\hline RC1.1 Early IP entry $[p]$ & Involved in early stages \\
\hline RC1.2 Continuous participation [p] & Involved in all stages \\
\hline RC1.3 Representation [s] & Multiple IP voices consulted \\
\hline RC1.4 Linguistic inclusivity $[\mathrm{s}]$ & IP language used \\
\hline$R C 1.5$ financial and technical resources [t] & Funding to cover participation-related costs \\
\hline RC1.6 Use of IP traditional knowledge [s] & Complies with IP rights \\
\hline$R C 1.7$ Turnover of IP representatives [t] & Minimised, for trustful relationships \\
\hline \multicolumn{2}{|l|}{ RA2. Value pluralism } \\
\hline RC2.1 IP control of process agenda [n] & Selecting issues to address \\
\hline RC2.2 Decision-making power $[\mathrm{n}]$ & IPs contribution \\
\hline RC2.3 Cultural / protocol pluralism [n] & All parties make equal efforts to interact \\
\hline RC2.4 Value / world-view pluralism [n] & $\begin{array}{l}\text { Traditional world-views and knowledge, } \\
\text { treated as valid and equal. }\end{array}$ \\
\hline \multicolumn{2}{|l|}{ RA3. Participation \& rights } \\
\hline RC3.1 Consultation [s] & $\begin{array}{l}\text { Finnish authorities negotiate with Sámi } \\
\text { Parliament / Skolt Village Assembly }\end{array}$ \\
\hline RC3.2 Negotiation $[s]$ & Direct interaction with government agencies \\
\hline RC3.3 Traditional knowledge [s] & Respected by State \\
\hline RC3.4 Use of biological resources [s] & For traditional purposes. \\
\hline
\end{tabular}


Assessment task was based on whether a review criterion in Table 1 was met by assigning 'yes'; or not met by assigning 'no'; or if present but not fully met by assigning 'partial'. This approach was also used in Early \& Morrison-Saunders (2008), and Baker \& McLelland (2003). The evaluation was applied to selected documents from Finnish environmental management projects in the Sámi homeland municipalities of Enontekiö, Inari, Utsjoki and the area of the reindeer owners' association of Lapland in Sodankylä (GoF, 1995a). In total, 31 documents were downloaded from the relevant authorities' websites:

- The Finnish Article 8j Working Group recommendations for implementing the CBD including the AK Guidelines.

- 20 Land Management and Use Plans (7 AK, 13 non-AK)

- Three EIAs for forest areas (two ending at screening; one discontinued after the first round of public comments (all non-AK))

- Five Natural Resource Plans (1 AK, 4 non-AK)

- Two county plans (both non-AK)

AK projects are those that followed the AK or utilised a dedicated AK working group at some stage, while non-AK projects did neither: allowing for comparison between them.

\subsubsection{Interview and questionnaire surveys}

Invitations to interviews were sent to public bodies (see Figure 3) which facilitate Sámi participation in environmental management, to complement and explain the review package findings. The Interviews were semi-structured and an option of a questionnaire was offered to potential interviewees who did not want to be interviewed. Both surveys had six openended questions on the strengths and weaknesses of Sámi consultation practice, and the opportunities and challenges of applying AK. Four interviews (about 45 minutes each) were conducted and three questionnaires were received. Figure 5 provides an overview of the methodology. 


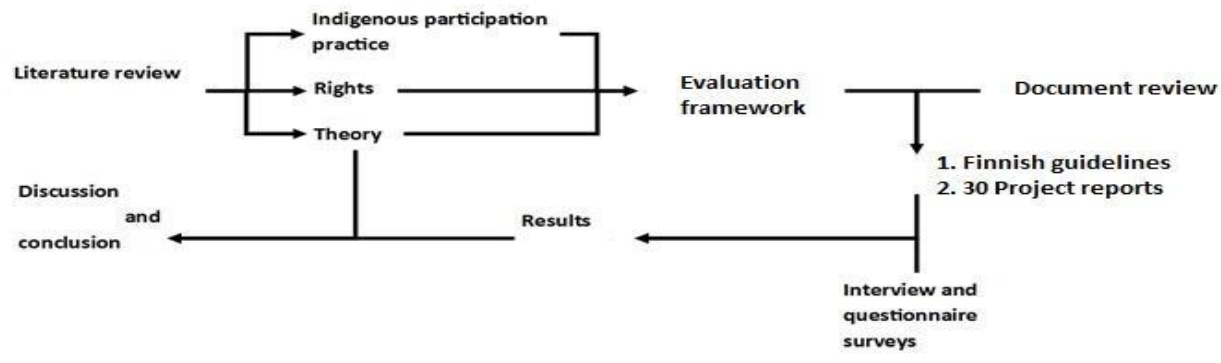

Figure 5. Schematic summary of the conceptual and procedural framework applied in the study

\section{Results and findings}

The results from reviewing the Finnish Guidelines or Article 8j Working Group documents are first presented, according to the RAs, followed by results from reviewing 30 environmental management project documents. Finally, results from the survey of respondents are presented, following the same RAs.

\subsection{Effectiveness review - Finnish guidelines}

\subsubsection{Information provision}

Information provision was very effective and all but one review category were met (85.7\%) (Figure 6). The goal of minimising staff and representative turnover was not directly addressed.

\begin{tabular}{|c|c|c|}
\hline $\begin{array}{l}\text { Information } \\
\text { provision }\end{array}$ & (Relevant section) in Akwé: Kon Guidelines & $\begin{array}{l}\text { Criterion } \\
\text { promoted? }\end{array}$ \\
\hline Early IP entry & $\begin{array}{l}\text { (16) facilitate involvement / participation of affected IPs, } \\
\text { local experts be identified, their expertise recognised and } \\
\text { engaged at earliest opportunity. }\end{array}$ & Yes \\
\hline $\begin{array}{l}\text { Continuous IP } \\
\text { participation }\end{array}$ & $\begin{array}{l}\text { (12) IPs invited to participate and accorded full respect at } \\
\text { all stages. }\end{array}$ & Yes \\
\hline $\begin{array}{l}\text { Representative } \\
\text { selection of IPs }\end{array}$ & $\begin{array}{l}\text { (17) community views and concerns properly recorded, } \\
\text { accounting for challenging logistics } \\
\text { (15) effective models of participation considered, } \\
\text { including regular feedback } \\
\text { (10) consider far-away and illiterate people } \\
\text { (51) ensure particular individuals or groups not unjustly } \\
\text { (dis)advantaged. } \\
\text { (54) women participation. }\end{array}$ & Yes \\
\hline $\begin{array}{l}\text { Linguistic } \\
\text { inclusivity }\end{array}$ & $\begin{array}{l}\text { (10) project notifications and consultations in language(s) } \\
\text { of IPs. }\end{array}$ & Yes \\
\hline
\end{tabular}




\begin{tabular}{lll}
\hline $\begin{array}{l}\text { Finance \& } \\
\text { technical } \\
\text { resources }\end{array}$ & $\begin{array}{l}\mathbf{( 1 8 )} \text { provide necessary human, financial, technical and } \\
\text { legal resources }\end{array}$ & Yes \\
\hline $\begin{array}{l}\text { Use of IP } \\
\text { traditional } \\
\text { knowledge }\end{array}$ & $\begin{array}{l}\mathbf{( 3 8 )} \& \mathbf{( 6 4 )} \text { traditional knowledge and practices } \\
\text { considered integral component of baseline studies }\end{array}$ & Yes \\
$\begin{array}{l}\text { Stable contact } \\
\text { persons }\end{array}$ & - & No \\
\hline
\end{tabular}

Figure 6: The Finnish Guidelines' reach on RA of information provision criteria

\subsubsection{Value pluralism}

This was rather ineffective as the RCs were either not or partially met, implying that the IPs were granted no decision-making power or control over the assessment agenda (Figure 7). The IPs were expected to participate fully in the cultural impact assessment, but their agency in conducting the assessment was presented as a possibility rather than an aim. Other forms of IP influence over assessment agenda were also framed as options rather than obligatory aims, as the Finnish Guidelines lacked acknowledgement of the equality of IPs world-views, values, and development priorities/paradigms. No explicit mention was made of cultural sensitivity in negotiations.

\begin{tabular}{|c|c|c|}
\hline $\begin{array}{l}\text { Normative } \\
\text { criterion }\end{array}$ & (Relevant section) in Akwé: Kon Guidelines & $\begin{array}{l}\text { Criterion } \\
\text { promoted in } \\
\text { Finnish } \\
\text { guidelines? }\end{array}$ \\
\hline $\begin{array}{l}\text { IP control of } \\
\text { process } \\
\text { agenda }\end{array}$ & $\begin{array}{l}\text { (14) IPs invited to participate in all EIA phases, including setting the } \\
\text { terms of reference for EIA } \\
\text { (6a) Cultural impact assessment involving IPs }\end{array}$ & Partial \\
\hline $\begin{array}{l}\text { IP decision- } \\
\text { making power }\end{array}$ & - & No \\
\hline $\begin{array}{l}\text { Cultural and } \\
\text { protocol } \\
\text { pluralism }\end{array}$ & $\begin{array}{l}\text { (12) IPs accorded full respect at all stages. } \\
\text { (17) Recording views in a manner consented to by IPs. } \\
\text { (29) Customary laws governing ownership, access, control, use and } \\
\text { dissemination of traditional knowledge, innovations and practices } \\
\text { observed. } \\
\text { (33 \& 34) Respect cultural sensitivities of IPs; clarify matters of } \\
\text { jurisdiction, minimise breaches of customary laws. } \\
\text { (45) consider 'importance of gender roles and relations', 'traditional } \\
\text { responsibilities and concepts of equity and equality in society', and } \\
\text { traditional economic and sharing systems. }\end{array}$ & Partial \\
\hline $\begin{array}{l}\text { Value and } \\
\text { world-view } \\
\text { pluralism }\end{array}$ & $\begin{array}{l}\text { (35), (37) recognise distinct activities, customs and beliefs of } \\
\text { affected IPs; sites of religious, spiritual, ceremonial and sacred } \\
\text { significance. }\end{array}$ & Partial \\
\hline
\end{tabular}

Figure 7: The Akwé: Kon Guidelines’ reach of normative criteria

However, when implementing Finnish Guidelines in the planning process under the Land Use and Building Act (GoF, 1999b), the planner must provide a reason for any decision not to accept a Sámi representative body's 
suggestion. This goes beyond the standard AK requirement of recording the views and concerns of indigenous and local communities.

\subsubsection{Legal rights}

Effectiveness was considerable, as the Guidelines required consultation with IPs representative institutions, promoting the realisation of the Sámi right to be consulted (Figure 8).

\begin{tabular}{|c|c|c|}
\hline $\begin{array}{l}\text { Participation \& } \\
\text { rights }\end{array}$ & (Relevant section) in Akwé: Kon Guidelines & $\begin{array}{l}\text { Criterion in } \\
\text { Finnish } \\
\text { guidelines? }\end{array}$ \\
\hline $\begin{array}{l}\text { Consultation right } \\
\text { (in force) }\end{array}$ & $\begin{array}{l}\text { (11) development proposal and impact assessment } \\
\text { availed to IP organisations }\end{array}$ & Yes \\
\hline $\begin{array}{l}\text { Negotiation right } \\
\text { (bill) }\end{array}$ & - & No \\
\hline CBD right & Relevant section in Akwé: Kon Guidelines & \\
\hline $\begin{array}{l}\text { Rights to } \\
\text { traditional } \\
\text { knowledge }\end{array}$ & $\begin{array}{l}\text { (23) conduct of impact assessments complies with CBD } \\
\text { Articles } 14 \text { and } 8(\mathrm{j}) \text {. }\end{array}$ & Yes \\
\hline $\begin{array}{l}\text { Rights to use } \\
\text { biological } \\
\text { resources }\end{array}$ & $\begin{array}{l}\text { (28) conduct of impact assessments complies with CBD } \\
\text { Article } 10(\mathrm{c}) \text {, on the diminution of the genetic diversity. }\end{array}$ & Yes \\
\hline
\end{tabular}

Figure 8: The Akwé: Kon Guidelines’ reach of rights criteria

Synthesising the RCs into the RAs (Table 2) reveals a semi-effective system that has room for improvement, especially in the areas of value plurality and promoting legal rights in substantive ways.

Table 2. Adding up Yes and No grades in the RCs to get to the RAs.

\begin{tabular}{|l|l|}
\hline Review Area & Summary of assessment and implication \\
\hline Information provision & $85.7 \%$ Yes, 25\% No; = Very good, with room for improvement \\
\hline Value pluralism & $75 \%$ Partial, 25\% No; = Good, with room for improvement \\
\hline Legal and rights & $75 \%$ Yes, 25\% No; = Fair, with significant room for improvement \\
\hline
\end{tabular}

\subsection{Effectiveness: environmental management plans}

This section draws on analysis from 30 different environmental management plans (Figure 9), showing wide variation in AK applications due to no established $\mathrm{AK}$ methods existing prior to the AK pilot project report (Metsähallitus, 2013). The three Management and Use Plans utilising an AK working group at every stage should be considered the best representation of AK practice, since this became standardised procedure following the conclusion of the pilot study. 


\begin{tabular}{lll}
\hline $\begin{array}{l}\text { Extent of Akwé: Kon } \\
\text { implementation }\end{array}$ & Project type & Total number \\
\hline Non-AK project & Management and Use Plan & 13 \\
\cline { 2 - 3 } & Natural Resource Plan & 4 \\
\cline { 2 - 3 } & County plan & 2 \\
\cline { 2 - 3 } & EIA & 3 \\
\hline $\begin{array}{l}\text { AK project: Increased } \\
\text { Sámi representation }\end{array}$ & Management and Use Plan & 1 \\
\cline { 2 - 3 } $\begin{array}{l}\text { AK project: Late entry of } \\
\text { AK working group }\end{array}$ & Matural Resource Plan & 1 \\
\hline $\begin{array}{l}\text { AK project: Early entry } \\
\text { and full involvement of }\end{array}$ & Management and Use Plan & 3 \\
AK working group & & \\
\hline All projects total & & 3 \\
\hline
\end{tabular}

Figure 9: Breakdown of environmental management projects

\subsubsection{Early and continuous participation}

Sámi participation in projects was typically secured through multistakeholder coordination panels which met about 3-5 times during the planning process. The exact point of Sámi entry was often ambiguous in the documents. 24 projects utilised Sámi-inclusive cooperation groups. Six nonAK projects, including the two EIAs (2015 and 2016), and two other projects from 2001 and 2008, were all ambiguous on the question. Two other Management and Use Plans (2008-9) indicated no continuous Sámi involvement. However, there was some indication that the guidelines did improve the continuity of Sámi participation, via AK working group representatives and the default Sámi Parliament representatives. This makes Sámi interaction with the planning authorities more continuous than that of other non-Sámi stakeholders in the coordination panels. According to the pilot study report (Metsähallitus, 2013), the AK working group attending Metsähallitus staff meetings benefitted the flow of information between parties.

\subsubsection{Representativeness}

Efforts to reach Sámi individuals outside the formal representative bodies were inconsistent. 13 projects with multi-stakeholder panels included Sámi representation from outside the official representative bodies, e.g. Sámi community organisations, Sámi business organisations, and the Sámi museum. There was only one attempt, in an EIA, to specifically reach organisationally unaffiliated Sámi individuals. The establishment of a dedicated AK working group evidenced ambiguous effects on inclusivity: it is appointed by the official Sámi representative bodies and some public comments criticise the make-up of the AK working group for non-inclusivity. 
Linguistic inclusivity was not effectively pursued as only four plans translated draft materials to a Sámi language. Three non-AK projects referenced the Sámi right to use their language but without specifying how. One non-AK EIA translated feedback surveys into two Sámi languages. However, the early AK projects showed efforts to promote language inclusivity, e.g. by facilitated interpretation at public events. The AK process appeared to bring more attention to articles $8 \mathrm{j}$ and $10 \mathrm{c}$ and encouraged utilising traditional knowledge. Five non-AK projects either referenced article $8 \mathrm{j}$ or repeated its content and one referenced article 10c. In contrast, all AK projects referenced both articles clearly. No non-AK projects contained evidence of efforts to utilise Sámi traditional knowledge in planning.

\subsubsection{Continuous participation}

Overall, evidence from the study showed that Sámi influence in environmental management projects was exerted through impact assessments, via participation in coordination panels, direct negotiations, and written consultation statements. In nine non-AK projects the authority delegated the Sámi cultural impact assessment to the Sámi Parliament. This can be seen as giving the Sámi some control of the process of planning and assessment. In five of these projects, documents also stated that planning followed aspects of the Sámi Sustainable Development Programme, which outlines the Sámi Parliament's policy preferences for sustainable and culturally sound environmental management. The AK pilot project report stated very directly that " $[\mathrm{t}] \mathrm{he}$ application of the AK Guidelines changes the impact assessment process into a continuous one" (Metsähallitus, 2013:27).

\subsubsection{Value pluralism}

Applying AK Guidelines does not shift decision-making power away from public authorities, nor do they address the important question of how far Sámi input leads to substantive changes and outcomes in the EIA process. Sámi values and worldviews are acknowledged to a very limited extent in both non-AK and AK projects, and their equality alongside dominant values is not affirmed. Only two non-AK projects made some reference to distinctive features of the Sámi worldview. They did so by describing the Sámi conceptions of 'wilderness' and 'cultural landscape' which differ from the Finnish understanding of the terms. Three AK projects recognised sacred sites. However, in three projects the Sámi Parliament accused Metsähallitus of treating increasing tourism or mining activity as a given, and of promoting a Finnish conception of development. The AK pilot report stated that the values guiding planning "are defined in consideration of a collaborative panel's views on the values of the area" (Metsähallitus, 2013:25), i.e. by multiple stakeholders, although values expressed by the AK working group are added 
into consideration as well. There is however no discussion of resolution mechanisms for potentially conflicting values between the coordination panel and the AK working group.

\subsubsection{Rights}

The Sámi consultation right was predominantly upheld and consultation generally took the form of direct interaction with authorities. There were four cases of completed projects which sought to consult the Sámi representative body by written statement only. Additionally, two projects had no consultation at all: one apparently due to the process predating current official Sámi representative bodies, and one apparently due to the plan being a specification to a pre-existing plan from the year before which had already carried out consultation. The documents of three AK projects stated that the negotiation requirement was met by the continuous participation of the AK working group.

\subsection{Interview and questionnaire surveys}

This section summarises practitioner views on the strengths and weaknesses of both AK and non-AK participation methods, grouped by theme. All direct quotes are translated by the researchers. Three respondents stated that they found the AK Guidelines were positive overall, although one respondent saw little added value in them. This sentiment was largely due to the respondent's interpretation that the guidelines applied to the participation of all locals, including Finns. Respondents affirmed that Sámi knowledge is valuable in the planning process. One respondent indicated that the AK process created additional work, and that unofficial cooperation with the Sámi outside of formal planning processes exists, and is a valuable aspect.

Five participants overall commented on the Sámi Parliament's ability to stick to timelines, as follows: the Sámi Parliament lacked sufficient resources to give all the input asked for; implementing AK Guidelines made the planning process longer; AK working groups could struggle to find appropriate times for meetings when its members have simultaneous responsibilities; lack of motivation on the part of some AK working group members; finding participants with the relevant local expertise could be difficult; and even AK working groups have not always produced the information they were expected to, leading to the authority having to find the relevant information itself.

One respondent indicated that the role of an independent secretary was essential in the AK process: "The Sámi are on average good in discussion and bringing up issues, but often the written side of things is lacking. The most difficult part of [the participation] process is to obtain the written product. This is why the group secretary has a highly important role. We have very 
well-functioning Akwé: Kon groups which still have not submitted the written product, the Sámi cultural impact statement."

In terms of Sámi relations with other parties, five respondents described Sámi participants as sometimes having a low willingness to compromise. One respondent expressed concern of yet worsening cooperation when AK Guidelines are applied: "To some extent the Sámi community has thought that [the AK Guidelines] are a new tool for them to oppose everything. I think it easily turns to that, and I find it unfortunate... for instance, as I remember the Sámi Parliament has given very similar and very negative statements to all gold washing projects."

One respondent said that Sámi and non-Sámi stakeholders did not necessarily trust one another, or doubted that the benefits were divided fairly, posing a challenge to planning. One addressed the Sámi Parliament's public negativity over consultation practices and characterised it as being foremost a political game: "At the end [of negotiations] we agreed to disagree on certain issues... [.]. It's a message to Helsinki, to those who don't know this culture, that something is wrong with the procedure."

Three respondents were concerned that AK implementation may create additional paper work without adding much value. Many of the AK aims were considered met when the public agency followed the law and the Sámi Parliament kept to schedules.

\section{Discussion}

It is significant that the results from a case study that is more advanced in terms of AK awareness and application, still echoes most of the commonly identified sources of ineffective IP participation in EIA. For example, Sámi Parliament lacking the resources to respond to all requests for input or Sámi representatives' disinterest or inability to complete their tasks have both been uncovered in other studies (see Markkula et al., 2019). However, it was clear that the AK may be effective in increasing the influence of the IPs by providing more space for the 'sharing of ideas' as argued in Blahna \& Keough (2005) and Markkula et al. (2019). Increased information flow between parties may also create opportunities for 'social learning' and innovative problem solving (O’Faircheallaigh, 2010). 


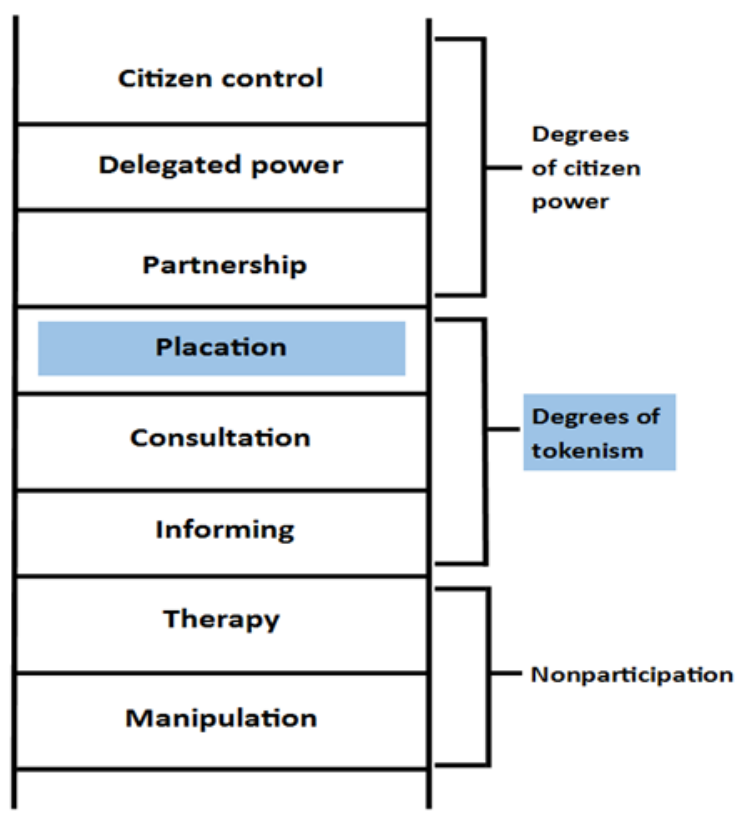

Figure 10. The Akwé Kon Guidelines mapped on Arnstein's ladder

Analysis in this study confirmed that the AK in various forms do not shift decision-making power, thus not giving real effect to the equality of IPs world-views, values, beliefs, and development paradigms, when considered among other Western perspectives. Following Arnstein's (1969) ladder of participation, the AK appear to promote 'placation' (Figure 10). In Finland, it appears that the guiding values of Metsähallitus' AK projects will continue to be generated cooperatively with multiple stakeholders and therefore not just focus on IPs.

Notably, the Finnish authorities already go beyond the requirements of consultation statutes to engage the Sámi, through unofficial meetings and annual meetings concerning ongoing plans between the Sámi Parliament and the Metsähallitus. Promoting the utilisation of traditional knowledge, with the consent of the concerned IPs, is one of the most significant impacts of the AK.

Traditional knowledge can supplement scientific understanding of ecologies, following Eira et al. (2013). However, in some cases, Finnish authorities have struggled to obtain the relevant expertise they are looking for among the IPs. Therefore, efforts to inventory traditional knowledge, as indicated by a study participant, could help overcome this hurdle. As the promotion of trust between indigenous and non-indigenous parties is an issue in Finland (Heinämäki, 2017), using insight from this study to enhance AK effectiveness can hopefully ameliorate these tensions. For example, long-term retention of Sámi negotiators and perceived fairness of the overall participation system can positively impact on trust. Sámi dissatisfaction 
appear to be rooted not in participation and/or negotiation practices, but in the political and legal conditions by which Sámi institutions, traditional lands and waters, are controlled by the Finnish state. Thus, the indigenous selfdetermination and participation rights that are intended as corrective measures against the prevailing distribution of sovereignty are not fully realised.

While AK is supposed to promote and assure quality IP participation in environmental management practices, including EIAs, findings from western countries have revealed ineffectiveness in some substantive respects, e.g. giving IPs power to meaningfully influence key decisions about control of their natural resources. This leaves room for significant improvement within EIA itself (Noble et al., 2016; O'Faircheallaigh, 2007, 2010; Booth \& Skelton, 2011). The EIA community, especially in jurisdictions with IPs, should formulate EIA policy and practice that give AK more effective translation (Jalava et al., 2010; Markkula et al., 2019), with auditable monitoring and enforceability.

This study highlights the need to address who is referred to in the AK term 'indigenous and local communities', perhaps aligned to the CBD recent definition. Thus: local communities have long association and dependence of the lands they have traditionally lived on or used and "have accumulated knowledge, innovations and practices regarding the sustainable management and development of these territories including useful environmental knowledge" (UNEP, 2011:1). Irrespective of what one makes of this description, an interpretation of 'indigenous and local communities' to include other Finns is dubious considering that the Finnish government and the multistakeholder Article 8j Working Group - tasked with establishing AK practices - both state that the AK Guidelines are applied to projects "with impacts on Sámi culture, livelihoods, and cultural heritage" (Ministry of the Environment, 2013:11).

A normative ethical argument against including all Finns in the scope of the term is that indigenous law (including CBD which is the foundation of the AK Guidelines) is fundamentally a corrective measure against past unjust dispossession and current political marginalisation (Macklem, 2008). Therefore, public participation serves an emancipatory and compensatory purpose of promoting the marginalised voices (Driessen et al., 2013); thus making everybody an equal beneficiary of the AK process defeats its purpose (Heinämäki, 2017). Nonetheless, it must be recognised that since the Sámi homeland is shared by all Finns, finding a fair and broadly accepted distribution of benefits and power with all the Finns could be politically challenging.

In terms of methodological constraints, experiences of AK application thus far are quite limited, and AK projects with comprehensive standardised AK approaches are only beginning to become mainstream following 
completion of the Hammastunturi pilot project in 2012. Therefore, these findings are largely provisional. Once practical experience of AK applications accumulates and procedures are entrenched, more focus can be given to Finnish AK participation practice and their substantive outcomes. Assessing the procedural merits of the guidelines' text as undertaken in this study is however valid irrespective of the number of AK projects. Studying substantive effectiveness would require far more comprehensive data collection than presented in this study.

Some potentially useful review areas identified from the literature review, e.g. adequate financial and technical resources, stability of contact persons, or cultural and protocol pluralism, could not be assessed from the documents, as the data was not evident. The documents were also generally not explicit about many other effectiveness criteria such as the point of entry or 'continuity' of Sámi participation. Additionally, many effectiveness criteria were poorly, only partially, or inconsistently addressed in selected documents, further raising the limitations of the methodology. It is therefore essential to keep in mind that the complete lack of information concerning an effectiveness criterion in the documents we studied may not categorically imply that the criterion was not addressed in practice.

\section{Conclusion}

In this study, the research question focused on the extent to which the AK Guidelines (AK) provided for effective IP participation. This was based on applying the Lee and Colley (1999) evaluation framework using criteria distilled from international literature, as applied to 31 documents from the Finnish context. A survey of seven key informants supplemented the methodology. Overall, the AK appeared generally effective in promoting information provision principles, and setting positive normative standards for respecting IPs' cultures and norms. However, they fell short of affirming the equality of IPs world-views, values, and development priorities. The AK helped align with the basic Finnish legal standards for Sámi consultation, while further promoting the realisation of articles 8(j) and 10(c) of the CBD on IPs rights. The AK's two most important contributions to Finnish environmental management appear to be promoting the use of Sámi traditional knowledge in planning, while affirming Sámi rights to that knowledge, and promoting more continuous Sámi involvement in impact assessment.

However, it is clear from the results that effective AK application is dependent on enough resourcing, AK working groups risk being insufficiently representative of Sámi interests. The AK may advance Sámi influence but do so without redistributing formal power. Thus, it may not resolve the tension between Sámi interests and competing non-Sámi interests in lands where Sámi cultural autonomy and self-determination should in principle prevail but are 
in practice politically contested. It is therefore difficult to see how the AK could therefore correct the deeper causes of Sámi dissatisfaction in environmental management. Many Sámi environmental interests are ultimately curtailed by their lack of decision-making power and the limits of the competent authorities' legal mandates, besides mere participation itself.

Perhaps the Finnish guidelines could be made more effective by explicitly requiring for active efforts to accommodate Sámi negotiation protocols, which may substantially differ from those of the developer or facilitating government agency. The EIA liaison authority, ELY-centre, within the spirit of the Finnish Guidelines, could ensure explicit attention is paid to the concerns raised by the Sámi representative bodies. Also, the ELY-centre and planner could ask for Sámi opinion on the sufficiency of the EIA process and its outcomes, including how the proposed development takes account of impacts to Sámi culture and living conditions. Relevant questions for future studies include: Which Sámi interests are best promoted in an AK process and which practical issues does the utilisation of Sámi traditional knowledge address? To what degree are the requirements of articles $8 \mathrm{j}$ and $10 \mathrm{c}$ met substantively?.

To the rest of the EIA community beyond Finland, this paper has demonstarted that there is signficant potential and scope to use the AK to promote IP particpation in EIA. This can enhance IP participation in protecting their rights and involvement in the governance of their environmetal resources. The effectiveness and potential value of the AK is food for thought, towards exploring how EIA regimes could better integrate AK into their training, policy, regulatory and practice frameworks. This must not be taken lightly in developing countries, especially in Sub-Saharan Africa, where indigenous communities close to the CBD definition are prevalent.

\section{References:}

1. Allard C., Heinämäki L. \& Kirchner S. (2017) Keskeisimmät johtopäätökset. In: Saamelaisten oikeuksien toteutuminen: kansainvälinen oikeusvertaileva tutkimus (Allard C., Bankes N., Gilbert J., Heinämäki L., Kirchner S. et al.). Valtioneuvoston selvitysja tutkimustoiminnan julkaisusarja 4/2017. Helsinki: Prime Minister's Office. Ch.15.

2. Anaya J. (2011) Report of the Special Rapporteur on the situation of human rights and fundamental freedoms of indigenous people: The Situation of the Sámi in the Sápmi region of Norway, Sweden and Finland. (A/HRC/18/35/Add.2) http://www.ohchr.org/EN/Issues/IPeoples/SRIndigenousPeoples/Pag es/CountryReports.aspx (30.3.2019). 
3. Arnstein S. R. (1969) A Ladder of Citizen Participation. Journal of the American Institute of Planners, 35(4), pp. 216-224.

4. Baker D. C. \& McLelland J. N. (2003) Evaluating the effectiveness of British Columbia's environmental assessment process for first nations' participation in mining development. Environmental Impact Assessment Review, 23, pp. 581-603.

5. Banerjee S. B. (2001) Corporate Citizenship and Indigenous Stakeholders: Exploring a New Dynamic of OrganisationalStakeholder Relationships. Journal of Corporate Citizenship, 1(1), pp. 39-55.

6. Barber M. \& Jackson S. (2015) Recognizing indigenous water cultures and rights in mine water management: the role of negotiated agreements. Aquatic Procedia, 5, pp. 81-89.

7. Beavis A., Escott H. \& Reeves A. (2015) Incentives and constraints to Indigenous engagement in water management. Land Use Policy, 49, pp.382-393.

8. Bersaglio B., Enns C. \& Kepe T. (2014) Indigenous voices and the making of the post-2015 development agenda: the recurring tyranny of participation. Third World Quarterly, 35:3, pp. 358-375.

9. Blahna D. J. \& Keough H. L. (2005) Achieving Integrative, Collaborative Ecosystem Management. Conservation Biology, 20:5, pp. 1373-1382.

10. Bond A. \& Chanchitpricha C. (2013) Conceptualising the effectiveness of impact assessment processes. Environmental Impact Assessment Review, 43, pp. 65-72.

11. Booth L. A. \& Skelton N. W. (2011) Industry and government perspectives on First Nations' participation in the British Columbia environmental assessment process. Environmental Impact Assessment Review, 31, pp. 216-225.

12. Carter L. \& Ruwhiu D. (2016) Negotiating "meaningful participation" for Indigenous peoples in the context of mining. Corporate Governance, 16:4, pp. 641-654.

13. Charters C. (2010) A Self-Determination Approach to Justifying Indigenous Peoples' Participation in International Law and Policy Making. International Journal on Minority and Group Rights, 17, pp. 215-240.

14. Chebotarev G. \& Gladun E. (2015) Participation of the Northern Indigenous Peoples in the Management of the Russian Arctic Territories and Its Legal Protection. The NISPAcee Journal of Public Administration and Policy, 8:1, pp. 111-133.

15. Collen W., Krause T. \& Nicholas K. A. (2013) Evaluating Safeguards in a Conservation Incentive Program: Participation, Consent, and 
Benefit Sharing in Indigenous Communities of the Ecuadorian Amazon. Ecology and Society, 18(4), art. 1.

16. Corbett T. \& O'Faircheallaigh C. (2005) Indigenous participation in environmental management of mining projects: The role of negotiated agreements. Environmental Politics, 14(5), pp. 629-647.

17. Driessen P. P. J., Glucker A. N., Kolhodd A. \& Runhaar H. A. C. (2013) Public participation in environmental impact assessment: why, who and how? Environmental Impact Assessment Review, 43, pp. 104111.

18. Early G. \& Morrison-Saunders A. (2008) What is necessary to ensure natural justice in environmental impact assessment decision-making. Impact Assessment and Project Appraisal, 26:1, pp. 29-42.

19. Flemmer R. \& Schilling-Vacaflor (2016) Unfulfilled promises of the consultation approach: the limits to effective indigenous participation in Bolivia's and Peru's extractive industries. Third World Quarterly, 37:1, pp. 172-188.

20. Fontana L. B. \& Grugel J. (2016) The Politics of Indigenous Participation Through "Free Prior Informed Consent": Reflections from the Bolivia Case. World Development, 77, pp. 249-261.

21. Gneiting U., Bruno-Van V T. \& Schmitz H P. (2009) Setting Higher Goals: Rights and Development. Monday Development, 27 (12),pp. 19-20.

22. Government of Finland (1995a) Act on the Sámi Parliament (974/1995). Available:

http://www.finlex.fi/en/laki/kaannokset/1995/en19950974 (30.3.2019).

23. Government of Finland (1995b) Kolttalaki (253/1995). Available: http://www.finlex.fi/fi/laki/alkup/1995/19950253 (30.3.2019).

24. Government of Finland (1999a) The Constitution of Finland (731/1999). Available:

http://www.finlex.fi/en/laki/kaannokset/1999/en19990731 (30.3.2019).

25. Government of Finland (2016) Laki metsähallituksesta (234/2016). Available:

http://www.finlex.fi/fi/laki/alkup/2016/20160234 (30.3.2019).

26. Guenther, M., Kenrick, J., Kuper, A., Plaice, E., Thuen, T., Wolfe, P., Zips, W. and Barnard, A. (2006) The Concept of Indigeneity. Social Anthropology, 14:1, pp. 17-32.

27. Harris-Curtis, E. (2003) Rights-Based Approaches: Issues for NGOs. Development in Practice, 13:5, pp. 558-564. 
28. Hausam S. (2013) Maybe, Maybe Not: Native American Particiaption in Regional Planning. In: Reclaiming Indigenous Planning (ed. Natcher D.C., Walker R.C. \& Jojola T.S.). Montréal: MQUP. Ch.7.

29. Heinämäki L. (2017a) Saamelaisten oikeudet Suomessa. In: Saamelaisten oikeuksien toteutuminen: kansainvälinen oikeusvertaileva tutkimus (Allard C., Bankes N., Gilbert J., Heinämäki L., Kirchner S. et al.). Valtioneuvoston selvitys- ja tutkimustoiminnan julkaisusarja 4/2017. Helsinki: Prime Minister's Office. Ch.2.

30. Howitt R. (2001) Rethinking Resource Management: Justice, Sustainability and Indigenous Peoples. London: Routledge.

31. Jalava K., Kuitunen M., Pasanen S. \& Saalasti M. (2010) Quality of Environmental Impact Assessment: Finnish EISs and the opinions of EIA professionals. Impact Assessment and Project Appraisal, 28:1, 15-27.

32. Johnsen K. I. (2016) Land-use conflicts between reindeer husbandry and mineral extraction in Finnmark, Norway: contested rationalities and the politics of belonging. Polar Geography, 39:1, 58-79.

33. Joona J. \& Joona T. (2011) The Historical Basis of Saami Land Rights in Finland and the Application of ILO Convention No. 169. Yearbook of Polar Law Online, 3:1, 351-388.

34. Kosko J. (2013) Agency vulnerability, participation, and the selfdetermination of indigenous peoples. Journal of Global Ethics, 9:3, pp. 293-310.

35. Lee N. \& Colley R. (1991) Reviewing the quality of environmental statements. Town Planning Review, 62:2, 239-248.

36. Lee N, Colley R, Bonde J \& and Simpson J. (1999) Reviewing the Quality of Environmental Statements and Environmental Appraisals. University of Manchester: Occasional Paper Number 55. Available at , Available from:

http://www.sed.manchester.ac.uk/planning/research/public ations/wp/eia/documents/OP55.pdf\#search='reviewing+the+quality+ of+environmental+statements+and+environmental+appraisals' (12.10.2019).

37. Macklem P. (2008) Indigenous Recognition in International Law: Theoretical Observations. Michigan Journal of International Law, 30:1, pp. 177-210. 
38. Markkula, I., Turunen, M and Kantola, S. (2019) Traditional and local knowledge in land use planning: insights into the use of the Akwé: Kon Guidelines in Eanodat, Finnish Sámi - Ecology and Society, 2019 - ecologyandsociety.org

39. Metsähallitus (2013) Loppuraportti: Akwé: Kon. Ohjeiden soveltaminen Hammastunturin erämaa-alueen hoito- ja käyttösuunnitelmassa. Rovaniemi: Metsähallitus.

40. Ministry of the Environment (2013) Luonnon puolesta - ihmisen hyväksi. Valtioneuvoston periaatepäätös Suomen luonnon monimuotoisuuden suojelun ja kestävän käytön strategiaksi vuosiksi 2012-2020. Available:

http://www.ym.fi/fi-

FI/Luonto/Luonnon_monimuotoisuus/Strategia_ja_toimintaohjelma (8.3.2019).

41. Minter T., Ploeg J. v. d., Pedrablanca M., Sunderland T. \& Pesoon G. A. (2014) Limits to Indigenous Participation: The Agta and the Northern Sierra Madre Natural Park, the Philippines. Human Ecology: An Interdisciplinary Journal, 42, pp. 769-778.

42. Niemivuo M. (2015) Human and Fundamental Rights of the Sámi. The Yearbook of Polar Law, VII, pp. 290-316.

43. Noble B., Poelzer G. \& Udofia A. (2016) Meaningful and efficient? Enduring challenges to Aboriginal participation in environmental assessment. Environmental Impact Assessment Review, in press, available:

http://www.sciencedirect.com/science/article/pii/S019592551530053 $6(30.3 .2019)$.

44. Nygaard V. (2016) Do indigenous interests have a say in planning of new mining projects? Experiences from Finnmark, Norway. The Extractive Industries and Society, 3, pp. 17-24.

45. O'Faircheallaigh C. (2007) Environmental agreements, EIA follow-up and aboriginal participation in environmental management: The Canadian experience. Environmental Impact Assessment Review, 27, pp. 319-342.

46. O'Faircheallaigh C. (2010) Public participation and environmental impact assessment: purpose, implications, and lessons for public policy making. Environmental Impact Assessment Review, 30, pp. 1927. 
47. Parks, L., Wim P, Lennan M. (2019) Guidelines and Codes on the Participation of Indigenous Peoples and Local Communities of the Convention on Biological Diversity: A Comparative Analysis Using Natural Language Processing, BENELEX Working Paper No 23.

48. Põder T \& Lukki T. (2011) A critical review of checklist-based evaluation of environmental impact statements. Impact Assessment and Project Appraisal, 29:1, 27-36.

49. Pogge, T. (2005) World Poverty and Human Rights. Ethics and International Affairs, 19:1, pp. 1-7.

50. Sadler B. (1996) International Study of the Effectiveness of Environmental Assessment, Final Report. Ottawa: Canadian Environmental Assessment Agency.

51. Convention on Biological Diversity. (2004) Akwé: Kon Guidelines. Montreal: Secretariat of the Convention on Biological Diversity.

52. Simpson J. (2001) Developing a review package to assess the quality of EA reports of Local Authority structure and local plans in the UK. Environmental Impact Assessment Review, 21:1, 83-95.

53. Simpson L. (2006) The Legacy of Deskaheh: Decolonising indigenous participation in sustainable development governance. In: The Politics of Participation in Sustainable Development Governance (ed. Green J. F. \& Chambers W. B.). New York: United Nations University Press. Ch.5.

54. United Nations Environment Programme. (2011) Guidance for the discussion concerning local communities within the context of the Convention on Biological Diversity, (UNEP/CBD/AHEG/LRC/1/2) 7 July 2011. Available: https://www.cbd.int/doc/?meeting=AHEGLCR-01 (30.3.2019).

55. United Nations General Assembly (UNGA). (2007) Resolution 61/295: Universal Declaration on the Rights of Indigenous Peoples, (A/RES/61/295) 2 October 2007. Available:

http://www.un.org/esa/socdev/unpfii/documents/DRIPS_en.pdf (1.4.2019). 